\title{
Salinomycin efficiency assessment in non-tumor (HB4a) and tumor (MCF-7) human breast cells
}

\author{
Andressa Megumi Niwa ${ }^{1}$ Gláucia Fernanda Rocha $D^{\prime}$ Epiro $^{1}$ • Lilian Areal Marques ${ }^{1}$. \\ Simone Cristine Semprebon ${ }^{1}$ - Daniele Sartori ${ }^{1}$ - Lúcia Regina Ribeiro ${ }^{2}$. \\ Mário Sérgio Mantovani ${ }^{1}$
}

Received: 12 November 2015 / Accepted: 24 February 2016/Published online: 2 March 2016

(C) Springer-Verlag Berlin Heidelberg 2016

\begin{abstract}
The search for anticancer drugs has led researchers to study salinomycin, an ionophore antibiotic that selectively destroys cancer stem cells. In this study, salinomycin was assessed in two human cell lines, a breast adenocarcinoma (MCF-7) and a non-tumor breast cell line (HB4a), to verify its selective action against tumor cells. Real-time assessment of cell proliferation showed that HB4a cells are more resistant to salinomycin than MCF-7 tumor cell line, and these data were confirmed in a cytotoxicity assay. The half maximal inhibitory concentration $\left(\mathrm{IC}_{50}\right)$ values show the increased sensitivity of MCF-7 cells to salinomycin. In the comet assay, only MCF-7 cells showed the induction of DNA damage. Flow cytometric analysis showed that cell death by apoptosis/necrosis was only induced in the MCF-7 cells. The increased expression of GADD45A and CDKN1A genes was observed in all cell lines. Decreased expression of $C C N A 2$ and $C C N B 1$ genes occurred only in tumor cells, suggesting G2/M cell cycle arrest. Consequently, cell death was activated in tumor cells through strong inhibition of the antiapoptotic genes $B C L-2, B C L-X L$, and $B I R C 5$ genes in MCF-7 cells. These data demonstrate the selectivity of salinomycin in killing human mammary tumor cells. The cell death observed only in MCF-7 tumor cells was confirmed by gene expression analysis, where there was downregulation of
\end{abstract}

Mário Sérgio Mantovani

biomsm@uel.br

1 Laboratório de Genética Toxicológica, Universidade Estadual de Londrina-CCB-BIO, Campus Universitário-Caixa Postal 10011, Rodovia Celso Garcia Cid (PR-445), Km 380, Londrina, Paraná CEP 86057-970, Brazil

2 Departamento de Patologia, Universidade Estadual Paulista, Botucatu, São Paulo, Brazil antiapoptotic genes. These data contribute to clarifying the mechanism of action of salinomycin as a promising antitumor drug and, for the first time, we observed the higher resistance of HB4a non-tumor breast cells to salinomycin.

Keywords Salinomycin · Cancer · Cytotoxicity · Genotoxicity $\cdot$ Apoptosis

\section{Introduction}

Cancer is one of the most concerning diseases for researchers because of its increasing incidence worldwide. Two factors hindering cancer treatment are chemotherapy resistance and disease recurrence. Furthermore, most current anticancer drugs fail to act selectively against tumor cells, also causing the death of healthy cells and generating a variety of side effects (Chari 2008).

Salinomycin is one such drug; it is an ionophore antibiotic produced by fermentation of Streptomyces albus (Miyazaki et al. 1974). Salinomycin is used to treat coccidiosis in poultry (chickens, turkeys, and quails) and in ruminants ( $\mathrm{Li}$ et al. 2010; Ivanova et al. 2011). Furthermore, salinomycin is used as a food additive in cattle to change the microbial composition of the rumen (Callaway et al. 2003). Antitumor activity of salinomycin was showed first time in 2009 (Gupta et al. 2009 ), who examined approximately 16,000 compounds and found that salinomycin had the best results against tumor cells. In that study, salinomycin showed selective activity against cancer stem cells 100 times more effectively than paclitaxel, a chemotherapy agent commonly used for breast cancer treatment. Cancer stem cells account for a small part of the tumor and show both resistance to current therapies (chemotherapy and radiotherapy) and regenerative capacity, leading to metastasis and disease recurrence (Eyler and Rich 2008). Further 
studies on salinomycin (Fuchs et al. 2009; Zhi et al. 2011; Kim et al. 2012; Arafat et al. 2013; He et al. 2013; Kim et al. 2013) have emerged basing on these studies.

Salinomycin induced apoptotic death in human cancer cells of multiple origins, including in apoptosis-resistant cell lines, whereas no effect was observed in normal cell lines, including human lymphocytes (Fuchs et al. 2009). Other studies conducted using osteosarcoma stem cells (Tang et al. 2011), prostate cancer cells (Kim et al. 2011; Ketola et al. 2012), nonsmall-cell lung cancer cell lines (Arafat et al. 2013; Li et al. 2013), a pancreatic cancer cell line (He et al. 2013), a gastric cancer cell line (Zhi et al. 2011), a hepatocellular carcinoma cell line (Wang et al. 2012), and an ovarian cancer cell line (Koo et al. 2013) showed the efficacy of salinomycin in targeting tumor cells.

Although several studies have suggested that salinomycin is a promising drug against various types of cancer, several authors have reported its toxicity in horses (Rollinson et al. 1987), turkeys (Griffiths et al. 1989), pigs (Kavanagh and Sparrow 1990), cats (van der Linde-Sipman et al. 1999), humans (Story and Doube 2004), and calves (Omidi 2010), and it shows neurotoxicity in cells from primary mouse embryos (Boehmerle and Endres 2011). Studies on its toxicity and side effects are necessary for identifying its putative mechanisms of action before it can be recommended as a chemotherapeutic drug.

Flow cytometric studies of the cell cycle phases and of apoptosis induction, among others, combined with the assessment of molecular markers of gene expression by real-time quantitative polymerase chain reaction (RT-qPCR) may help identify the effects of new drugs in the fight against cancer. Cancer is characterized by abnormal cell proliferation, characteristic shown in several tumor cell lines with different genetic disorders involved in carcinogenesis. Therefore, cell culture experiments are important for the evidence-based in vitro study of the main therapeutic approaches to cancer. Thus, given the promising use of salinomycin in cancer treatment and because its mechanism remains little known, the present study aimed to assess the selective activity of salinomycin against human tumor cells and to clarify its mechanism of action. For this purpose, salinomycin was tested in two mammary human cell line, a tumor and a non-tumor cell line regarding cytotoxicity, genotoxicity, apoptosis induction, cell cycle, and expression analysis of genes involved in cell cycle control, apoptosis induction, and the DNA damage response.

\section{Materials and methods}

\section{Cell culture}

The human breast adenocarcinoma line MCF-7 (Michigan Cancer Foundation-7) and the non-tumor human breast epithelial cell line HB4a were used in this study. The cells were grown in $25-\mathrm{cm}^{2}$ culture flasks containing Dulbecco's Modified Eagle Medium (DMEM, Gibco, Life Technologies), supplemented with $10 \%$ fetal bovine serum (FBS; Gibco, Life Technologies), and maintained in a $5 \% \mathrm{CO}_{2}$ incubator at $37^{\circ} \mathrm{C}$ (Ultrasafe HF $212 \mathrm{UV}$ ). The cell lines were supplemented with insulin (Gibco, Life Technologies) and hydrocortisone $(5 \mu \mathrm{g} / \mathrm{ml})$. The MCF-7 cell line was purchased from the Cell Bank of Rio de Janeiro and the cell line HB4a was kindly provided by the AC Camargo Cancer Center (Hospital AC Camargo; São Paulo, SP).

\section{Chemical agents}

Salinomycin $\left(\mathrm{C}_{42} \mathrm{H}_{70} \mathrm{O}_{11}\right)$, extracted from S. albus, was purchased from Sigma (S4526) and diluted in dimethylsulfoxide (DMSO; Acros Organics). The DMSO concentration did not exceed $0.25 \%$ in the culture medium. In the Real-Time Cell Analyzer (RTCA) and cytotoxicity assay (3-(4,5Dimethylthiazol-2-yl)-2,5-diphenyltetrazolium bromide, MTT assay), the chemotherapy agent doxorubicin (Adriblastina ${ }^{\circledR}$ ) (Pharmacia), diluted in DMEM to $5 \mu \mathrm{M}$, was used as a control for the induction of DNA damage. Furthermore, $1 \mu \mathrm{M}$ doxorubicin was used in the genotoxicity assessment. The dye Hoechst 33342 (Sigma) at $10 \mu \mathrm{g} / \mathrm{ml}$ was used for the morphological analysis of cells in the apoptosis induction analysis.

\section{Real-time cell analyzer}

The RTCA xCELLigence (Roche Diagnostic) enables the real-time assessment of the growth of cells with and without exposure to different concentrations of the compound of interest. This is possible because of gold microelectrodes coupled to the base of a 96-well culture plate called an $E$ Plate. Those electrodes are connected to a computer that measures differences in impedance within an electrical circuit (Martinez-Serra et al. 2014). The impedance reflects changes in adhesion or detachment of cells from the well, as well as changes in cell morphology (Roshan et al. 2015). Those data are converted into a cell index value: the greater the well surface area occupied by cells, the greater the cell index value. A titration was performed before starting the analysis to assess the number of cells that enable steady growth during the treatment period, without the cells reaching a plateau. The optimal number of cells must be defined to ensure that they will receive treatment at an optimal time, when the cells are in the exponential growth phase. The numbers of cells established were as follows: $3125 \mathrm{HB} 4 \mathrm{a}$ cells and $6250 \mathrm{MCF}-7$ cells per well, with $100 \mu \mathrm{l}$ media, in a 96-well plate. These numbers of cells and the amount of culture medium were maintained in the other tests. Cells were seeded in 96-well E-plates. The concentrations of $5,10,20,40$, and $80 \mu \mathrm{M}$ salinomycin were 
selected to assess the proliferation of the three cell lines. DMSO at $0.25 \%$ and $0.5 \%$ PBS buffer $(0.02 \% \mathrm{KCl}$, $0.02 \% \mathrm{KH}_{2} \mathrm{PO}_{4}, 0.8 \% \mathrm{NaCl}$, and $0.115 \% \mathrm{Na}_{2} \mathrm{HPO}_{4}$ ) were added to the culture media as the vehicle control. The treatments were added after $24 \mathrm{~h}$ of cell culture, and cell growth was monitored for $96 \mathrm{~h}$, with readings taken every $30 \mathrm{~min}$. The normalized cell index was calculated using the RTCA software (Roche Diagnostic, Germany). The experiments were performed in triplicate.

\section{Cytotoxicity assessment}

\section{MTT cytotoxicity assay}

The MTT cytotoxicity assay was performed as previously described (Mosmann 1983). This method is widely used for cytotoxicity, cell viability, and live cell proliferation analyses. The yellow tetrazolium salt MTT (Invitrogen Life Technologies, USA) is reduced to purple formazan (1-[4,5-dimethylthiazol2-yl]-3,5-diphenylformazan) in live cells. The formazan salt is dissolved in DMSO following its metabolism by live cells, and the solution can be analyzed colorimetrically in a spectrophotometer. Thus, the higher the number of viable cells, the greater the intensity of the purple color and the absorbance value. In this assay, 96-well culture plates were used with $100-\mu$ l culture media containing numbers of cells determined by titration. The wells corresponding to the blank received no cells. The system was incubated in a $5 \% \mathrm{CO}_{2}$ incubator at $37{ }^{\circ} \mathrm{C}$ for $24 \mathrm{~h}$ of cell culture. Next, the respective treatments were added to the culture media: vehicle control (culture medium with $0.25 \%$ DMSO and $0.5 \%$ PBS); positive control for DNA damage induction (doxorubicin $5 \mu \mathrm{M}$ ); and salinomycin 5, 10, 20, 40, or $80 \mu \mathrm{M}$. The cells were exposed to treatments for 24,48 , or $72 \mathrm{~h}$. Following the treatment periods, all contents of the wells were removed, and $100 \mu \mathrm{l}$ of $0.5 \mathrm{mg} / \mathrm{ml}$ MTT diluted in serumfree culture media was added to each well. The cells were then incubated at $37{ }^{\circ} \mathrm{C}$ for $4 \mathrm{~h}$. The MTT solution was removed from the wells after this period, and $100 \mu \mathrm{l}$ of DMSO was added to dilute the formazan crystals. The readings were taken using a spectrophotometer (Thermoplate) at $540 \mathrm{~nm}$. The assessments were performed in three experiments (plates) with five technical replicates of treatments/each plate.

\section{$I C_{50}$ calculation}

The calculation of the half maximal inhibitory concentration $\left(\mathrm{IC}_{50}\right)$, i.e., the concentration that inhibits $50 \%$ of the cell population, was performed using GraphPad Prism software version 5.00 (GraphPad Software, San Diego, California, USA). The cell viability values obtained in the MTT assay, after 24,48 , and $72 \mathrm{~h}$ of exposure to salinomycin, were used for the calculation. The calculation of percentage cell viability was performed using the absorbance values obtained in the MTT assay, by considering the control as $100 \%$ (Huang et al. 2005).

\section{Genotoxicity assessment—comet assay}

The comet assay was performed as previously described (Tice et al. 2000). For this purpose, 6-well culture plates were used with 5000 cells in 2 -ml culture medium. Salinomycin was assessed for its genotoxicity at concentrations of 10,20, and $40 \mu \mathrm{M}$. Doxorubicin $1 \mu \mathrm{M}$ was used as a positive control for DNA damage induction, and the vehicle control contained culture medium with $0.06 \%$ DMSO and $0.05 \%$ PBS. After $3 \mathrm{~h}$ of treatment, cells were harvested, centrifuged, resuspended in $0.5 \%$ low melting point (LMP) agarose, and distributed in pre-gelatinized slides with $1.5 \%$ agarose. Cells were immersed in lysis solution ( $1 \%$ Triton X-100, $10 \%$ DMSO, $14.61 \% \mathrm{NaCl}, 3.72 \%$ EDTA-titriplex, and $0.12 \%$ Tris) for $60 \mathrm{~min}$ at $4{ }^{\circ} \mathrm{C}$ and subjected to alkaline conditions in electrophoresis buffer $(0.5 \% 200 \mathrm{mM}$ EDTA-titriplex and $3 \% 10 \mathrm{~N}$ $\mathrm{NaOH}$ ) for $20 \mathrm{~min}$. Electrophoresis was performed at $\mathrm{pH} 13$, $25 \mathrm{~V}, 300 \mathrm{~mA}$ for $20 \mathrm{~min}$. Subsequently, the slides were neutralized using neutralizing solution $(4.85 \% 0.4 \mathrm{M}$ Tris, $\mathrm{pH} 7.5$ ) and fixed with absolute ethanol for $10 \mathrm{~min}$. The slides were stained with $100 \mu$ l ethidium bromide $(0.002 \mathrm{mg} / \mathrm{ml})$ and analyzed under a fluorescence microscope (Nikon) at a final magnification of $400 \times$. The comets were visually classified into classes 0 to 3 depending on tail length and intensity: (0) absence of tail; (1) tail with a length of up to $100 \%$ of the nucleoid (comet head) diameter; (2) tail with a length of up to $200 \%$ of the head diameter; and (3) tail longer than $200 \%$ of the head diameter. Thus, the longer the tail length, the higher the genotoxic damage. Cell viability was confirmed using the dye exclusion method with trypan blue. Cell viability higher than $80 \%$ was considered satisfactory. The score was calculated using the following equation: (class $0 \times 0+$ class $1 \times 1+$ class $2 \times 2+$ class $3 \times 3$ ). Three experiments were performed, with two slide replicates/each treatment. A total of 200 nucleoids were analyzed in each treatment, with 100 in each slide.

\section{Cell cycle analysis—-flow cytometry}

Cells were seeded $\left(1.25 \times 10^{5}\right.$ cells/well $)$ in 6-well culture plates. The culture medium was removed after $24 \mathrm{~h}$ of cell culture, and the new medium was added containing the following treatments: vehicle control, $0.06 \%$ DMSO; $0.05 \%$ PBS; and salinomycin, 10,20 , or $40 \mu \mathrm{M}$. The cells were exposed to treatments for $24 \mathrm{~h}$. Following the treatment period, the cells were detached from the flask using the Accutase reagent (Gibco, Life Technologies), centrifuged (2000 rpm for $5 \mathrm{~min}$ ), and resuspended in PBS. The samples were treated with RNase $\left(0.1 \mathrm{mg} / \mathrm{ml}\right.$; QIAGEN) for $30 \mathrm{~min}$ at $37^{\circ} \mathrm{C}$, then supplemented with a hypotonic fluorochrome solution (50 $\mathrm{mg} / \mathrm{ml}$ propidium iodide, $0.1 \%$ sodium citrate, and 
$0.1 \%$ Triton X-100), and placed on ice in the dark for $30 \mathrm{~min}$ (Savio et al. 2014). Next, the fluorescence of propidium iodide was estimated by flow cytometry (Accuri C6, BD Pharmingen ${ }^{\mathrm{TM}}$ ). The DNA content was analyzed based on the propidium iodide fluorescence intensity, and the percentages of cells at different phases of the cell cycle (G1, S, and $\mathrm{G} 2 / \mathrm{M}$ ) were estimated. A total of 10,000 events were acquired for each sample, and three experiments were performed.

\section{Cell death analysis}

\section{Flow cytometry (Annexin V/Propidium Iodide)}

The apoptosis analysis was performed using the Annexin V-FITC Apoptosis Detection Kit (BD Pharmingen) according to the manufacturer's protocol. The cells were seeded in 6-well culture plates, the culture medium was removed after $24 \mathrm{~h}$ of cell culture, and new medium was added containing the following treatments: vehicle control, $0.06 \%$ DMSO; $0.05 \%$ PBS; and salinomycin, 10,20 , or $40 \mu \mathrm{M}$. The cells were incubated for $24 \mathrm{~h}$. Following that incubation period, the cells were detached from the flask using the Accutase reagent (Gibco, Life Technologies), centrifuged (2000 rpm for $5 \mathrm{~min}$ ), and washed twice in ice-cold PBS. After the centrifugations, the cells were resuspended in Annexin V-binding buffer $(1 \times)$ and labeled with the fluorochromes Annexin V-fluorescein isothiocyanate (AV-FITC) and propidium iodide (PI) for $15 \mathrm{~min}$ in the dark. The samples were analyzed by flow cytometry (Accuri C6, BD Pharmingen ${ }^{\mathrm{TM}}$ ) using the software BD Accuri C6. Three cell populations were defined according to the labeling with fluorochromes: viable cells (AV-/PI-); initial apoptosis (AV+/PI-); and final apoptosis/necrosis (AV $-/ \mathrm{PI}+\mathrm{AV}+/ \mathrm{PI}+)$. A total of 10,000 events were acquired for each sample, and three experiments were performed.

\section{Hoechst 33342 staining}

For visualizing the morphology of cells exposed to salinomycin, cells were stained with Hoechst 33342, a DNA-specific dye, which enables the visualization of cell nucleus under fluorescence microscopy (Chazotte 2011). Cells were seeded in 6-well culture plates, the culture medium was removed after $24 \mathrm{~h}$ of cell culture, and new medium was added containing the following treatments: vehicle control $(0.06 \%$ DMSO; $0.05 \%$ PBS); and salinomycin 10,20 , or $40 \mu \mathrm{M}$. Cell were incubated for $24 \mathrm{~h}$ and then exposed to the fluorochrome Hoechst 33,342 $(10 \mu \mathrm{g} / \mathrm{ml})$ for $20 \mathrm{~min}$ in the dark. Cells were analyzed using an inverted fluorescence microscope at $460 \times$ magnification (blue filter, 390/40 $\mathrm{nm}$ excitation and 446/ $33 \mathrm{~nm}$ emission-FLoid ${ }^{\circledR}$ Cell Imaging Station, Life Technologies). Images of the different treatments were captured and used to differentiate non-apoptotic cells from apoptotic cells. Cells with condensed chromatin and formation of apoptotic bodies were considered apoptotic.

\section{RT-qPCR}

For this analysis, 6-well culture plates were used, and the following treatments were added to the culture medium after 24 h of cell culture: vehicle control (0.06 \% DMSO; $0.05 \%$ PBS) and $40 \mu \mathrm{M}$ salinomycin. Cells were incubated for $24 \mathrm{~h}$. Next, total RNA was extracted using the RNeasy ${ }^{\circledR}$ Mini Kit (Qiagen, Cat. No. 74106) according to the manufacturer's protocol. Sample purity was assessed using a NanoDrop device (Thermo Scientific), and the sample integrity was assessed using $1 \%$ agarose gel electrophoresis. Subsequently, the complementary DNA (cDNA) was synthesized from $1 \mu \mathrm{g}$ of total RNA, using dNTPs (Invitrogen, Life Technologies), Oligo-dT (Invitrogen, Life Technologies) and the reverse transcriptase enzyme M-MLV (Invitrogen, Life Technologies). In the RT-qPCR assay, $5 \mu \mathrm{l}$ of cDNA was added to the reaction mixture containing the forward and reverse primers, which amplify partial regions of the transcripts of interest, and the dye SYBR Green (Bio-Rad), which fluoresces when binding to double-stranded DNA, in a reaction with a final volume of $12 \mu \mathrm{l}$. The reactions were performed in a Bio-Rad C1000 Touch $^{\mathrm{TM}}$ ThermalCycler (CFX96 ${ }^{\mathrm{TM}}$ RealTime System). Transcripts of genes related to DNA damage induction $(G A D D 45 A)$, the cell cycle (TP53, CCNA2, $C C N B 1, C D K N 1 A$, and $C T N N B 1)$, and apoptosis (BAX, $B A K, C A S P 7, C A S P 8, C A S P 9, B C L-X L, B C L-2$, and $B I R C 5$ ) were analyzed. $C A S P 3$ expression was assessed only in the HB4a cell line because MCF-7 cells do not express caspase-3 (Janicke 2009). The sequences of the primers are shown in Table 1. The amplification of fragments was detected by the fluorescence emitted by the fluorophore $\mathrm{SYBR}^{\circledR}$ Green Supermix (Bio-Rad). The following PCR parameters were used: one step of initial denaturation at $50^{\circ} \mathrm{C}$ for $2 \mathrm{~min}$; $95^{\circ} \mathrm{C}$ for $2 \mathrm{~min}$; and 45 cycles at $95^{\circ} \mathrm{C}$ for $15 \mathrm{~s}, 60^{\circ} \mathrm{C}$ for $15 \mathrm{~s}$ and $72{ }^{\circ} \mathrm{C}$ for $30 \mathrm{~s}$. The evaluation was performed in three experiments and reactions were performed in two mechanical replicates/treatment/experiments. The data were normalized using the genes glyceraldehyde-3-phosphate dehydrogenase $(G A P D H)$ and ribosomal protein L13a (RPL13A).

\section{Statistical analysis}

The data obtained in the RTCA, MTT cytotoxicity, comet, and flow cytometry (cell cycle and apoptosis) assays were analyzed by analysis of variance followed by Dunnett's test, using the software GraphPad Prism, version 5.00 (GraphPad Software, San Diego, California, USA), with $p<0.05$ considered significant when comparing the treatments with different salinomycin concentrations with the control group. The expression levels of the studied genes were determined as previously described (Pfaffl 2001), and the statistical analysis was performed using Relative Expression Software Tool (REST) 2009 v. 2.0.13 (Pfaffl et al. 2002). Differences in gene 
Table 1 Oligonucleotide primers used for RT-PCR

\begin{tabular}{|c|c|c|}
\hline Gene & Primers & Reference \\
\hline$A C T B$ & $\begin{array}{l}\text { F:5' CTG GCA CCC AGC ACA ATG 3' } \\
\text { R:5' GCC GAT CCA CAC GGA GTA CT 3' }\end{array}$ & {$[35]$} \\
\hline$B A X$ & $\begin{array}{l}\text { F:5' TTT CTG ACG GCA ACT TCA ACT GGG 3' } \\
\text { R:5' TGT CCA GCC CAT GAT GGT TCT GAT 3' }\end{array}$ & {$[36]$} \\
\hline$B A K$ & $\begin{array}{l}\text { F:5' CAA GAT TGC CAC CAG CCT GTT TGA 3' } \\
\text { R:5' ATG CAG TGA TGC AGC ATG AAG TCG } 3^{\prime}\end{array}$ & Present study ${ }^{\mathrm{a}}$ \\
\hline$B C L-2$ & $\begin{array}{l}\text { F:5' GAT TGT GGC CTT CTT TGA G 3' } \\
\text { R:5' GTT CCA CAA AGG CAT CC 3' }\end{array}$ & SIGMA \\
\hline$B C L-X L$ & $\begin{array}{l}\text { F:5' TGG GCT CAC TCT TCA GTC GGA AAT } 3^{\prime} \\
\text { R:5' ATG TAG TGG TTC TCC TGG TGG CAA } 3^{\prime}\end{array}$ & {$[37]$} \\
\hline BIRC5 & $\begin{array}{l}\text { F:5' AGC CCT TTC TCA AGG ACC AC 3' } \\
\text { R:5' TGG CTC GTT CTC AGT GGG GCA GT 3' }\end{array}$ & [38] with modifications \\
\hline CASP3 & $\begin{array}{l}\text { F:5' GTG CTA CAA TGC CCC TGG AT 3' } \\
\text { R:5' GCC CAT TCA TTT ATT GCT TTC C } 3^{\prime}\end{array}$ & [39] \\
\hline CASP7 & $\begin{array}{l}\text { F:5' TCA CCA TGC GAT CCA TCA AGA CCA 3' } \\
\text { R:5' TTT GTC TGT TCC GTT TCG AAC GCC } 3^{\prime}\end{array}$ & [36] \\
\hline CASP8 & $\begin{array}{l}\text { F:5' GCA AAA GCA CGG GAG AAA GT 3' } \\
\text { R:5' TGC ATC CAA GTG TGT TCC ATT C } 3^{\prime}\end{array}$ & {$[40]$} \\
\hline CASP9 & $\begin{array}{l}\text { F:5' CTC TAC TTT CCC AGG TTT } 3^{\prime} \\
\text { R:5' TTT CAC CGA AAC AGC ATT } 3^{\prime}\end{array}$ & SIGMA \\
\hline CCNA2 & $\begin{array}{l}\text { F:5' GAC CCT GCA TTT GGC TGT G } 3^{\prime} \\
\text { R:5' ACA AAC TCT GCT ACT TCT GG } 3^{\prime}\end{array}$ & [41] \\
\hline$C C N B 1$ & $\begin{array}{l}\text { F:5' AGA GCA TCT AAG ATT GGA GAG 3' } \\
\text { R:5' CCA TGT CAT AGT CCA ACA TAG 3' }\end{array}$ & SIGMA \\
\hline$C D K N 1 A$ & $\begin{array}{l}\text { F:5' CAG CAT GAC AGA TTT CTA CC } 3^{\prime} \\
\text { R:5' CAG GGT ATG TAC ATG AGG AG 3' }\end{array}$ & SIGMA \\
\hline$C T N N B 1$ & $\begin{array}{l}\text { F:5' CCT ATG CAG GGG TGG TCA AC 3' } \\
\text { R:5' CGA CCT GGA AAA CGC CAT CA 3' }\end{array}$ & {$[42]$} \\
\hline GADD $45 A$ & $\begin{array}{l}\text { F:5' TCA GCG CAC GAT CAC TGT C 3' } \\
\text { R:5' CCA GCA GGC ACA ACA CCA C 3' }\end{array}$ & Present study ${ }^{a}$ \\
\hline$G A P D H$ & $\begin{array}{l}\text { F:5' GAA GGT GAA GGT CGG AGT C 3' } \\
\text { R:5' GGA AGA TGG TGA TGG GAT TT 3' }\end{array}$ & [43] with modifications \\
\hline RPL13A & $\begin{array}{l}\text { F:5' CCT GGA GGA GAA GAG GAA AGA GA T 3' } \\
\text { R:5' TTG AGG ACC TCT GTG TAT TTG TCA A 3' }\end{array}$ & {$[44]$} \\
\hline TP53 & $\begin{array}{l}\text { F:5' TAC CAC CAT CCA CTA CAA CT 3' } \\
\text { R:5' GAC AGG CAC AAA CAC GCA C 3' }\end{array}$ & [45] with modifications \\
\hline
\end{tabular}

${ }^{\text {a }}$ Sequences of forward and reverse primers were designed according to IDT software (Integrated DNA Technologies) [46]

expression were considered significant when the change in expression was greater than two-fold.

\section{Results}

\section{Real-time cell analyzer}

When exposed to salinomycin, MCF-7 tumor cells were more sensitive to salinomycin than HB4a non-tumor cells (Fig. 1). A significant decrease in cell growth occurs in these tumor cells after $12 \mathrm{~h}$ of exposure to salinomycin at all concentrations tested. Conversely, salinomycin $10 \mu \mathrm{M}$ has no effect on the growth of the non-tumor cells (HB4a) during the first $24 \mathrm{~h}$ and, at $5 \mu \mathrm{M}$, cell growth remains similar to that of the control even after $48 \mathrm{~h}$ of treatment. All salinomycin concentrations decreased HB4a cell growth after $48 \mathrm{~h}$ of cell culture.

\section{Cytotoxicity assessment}

MTT cytotoxicity assay

Corroborating the data from the RTCA assay, the MTT cytotoxicity assay showed that MCF-7 tumor cells were more sensitive to salinomycin than were HB4a cells (Fig. 2). Salinomycin exhibited concentration- and time-dependent cytotoxicity against all cell lines. After $24 \mathrm{~h}$ of treatment, salinomycin was cytotoxic to MCF-7 
Fig. 1 Cell proliferation curves obtained using the real-time cell analyzer (RTCA) for MCF-7 (a) and HB4a (b) cells exposed vehicle control (DMSO $0.25 \%$; PBS $0.5 \%$ ) and to $5,10,20,40$, or $80 \mu \mathrm{M}$ salinomycin
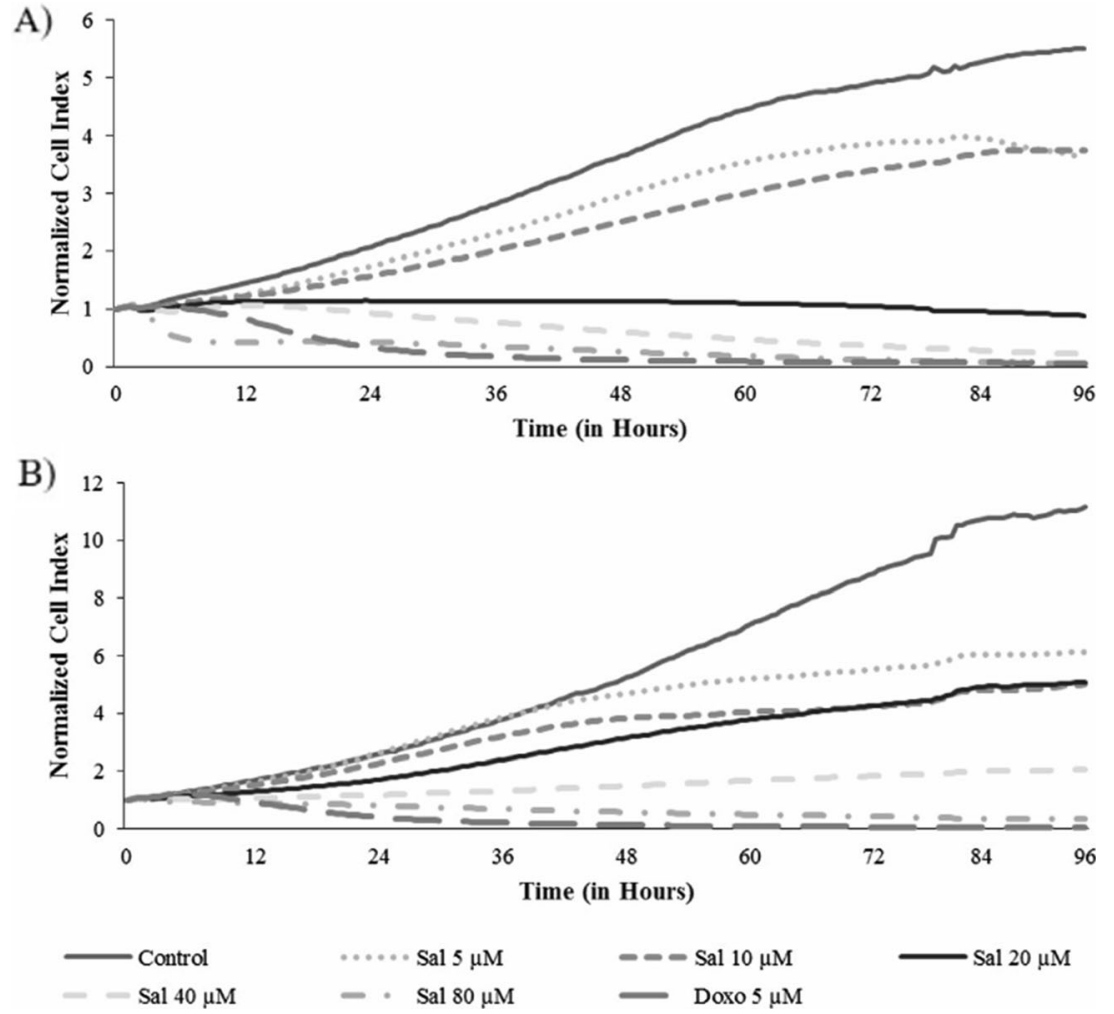

cells at concentrations of $20 \mu \mathrm{M}$ and higher, whereas salinomycin was cytotoxic to HB4a non-tumor cells only at $80 \mu \mathrm{M}$. All salinomycin concentrations tested were cytotoxic to MCF-7 cells after 48 and $72 \mathrm{~h}$ of treatment. Further, after $48 \mathrm{~h}$ of treatment, salinomycin was cytotoxic to HB4a cells at concentrations of $20 \mu \mathrm{M}$ and higher. At $72 \mathrm{~h}$, all concentrations were cytotoxic to these cell lines. Based on the results from the RTCA and MTT assays, the concentrations 10, 20 and $40 \mu \mathrm{M}$ were selected for further experiments.

\section{$I C_{50}$ calculation}

The $\mathrm{IC}_{50}$ was calculated after 24,48 and $72 \mathrm{~h}$ of exposure to salinomycin. The IC50 values were 28,20 , and $13 \mu \mathrm{M}$ in MCF-7 cells and 132, 43, and $20 \mu \mathrm{M}$ in HB4a cell line after 24, 48, and $72 \mathrm{~h}$, respectively, (Fig. 3). This data demonstrate that the HB4a cells showed higher resistance to salinomycin than did the tumor cell line. MCF-7 cells were more sensitive to salinomycin, showing lower $\mathrm{IC}_{50}$ values. At $24 \mathrm{~h}$ of treatment, HB4a cells were much more resistant to salinomycin than the tumor cell line, with $\mathrm{IC}_{50}$ values approximately 4.7 times higher than MCF-7. After $48 \mathrm{~h}$ of treatment, the $\mathrm{IC}_{50}$ of $\mathrm{HB} 4 \mathrm{a}$ cells dropped sharply, although it remained significantly higher than the MCF7 cell line. After $72 \mathrm{~h}$, the $\mathrm{IC}_{50}$ value for $\mathrm{HB} 4 \mathrm{a}$ cells was similar to the tumor cell line.

\section{Genotoxicity assessment}

The comet assay showed that salinomycin $40 \mu \mathrm{M}$ was genotoxic only to MCF-7 cells after $3 \mathrm{~h}$ of treatment (Fig. 4). No genotoxicity was observed at any concentration tested in HB4a cells.

\section{Cell cycle analysis}

Cell cycle analysis by flow cytometry showed that salinomycin was capable of changing the distribution of MCF-7 cells in the cell cycle phases, but there was no significant difference compared to the control in the non-tumor cell line HB4a (Fig. 5). Exposure of MCF-7 breast tumor cells to salinomycin $20 \mu \mathrm{M}$ decreased the number of cells in $\mathrm{S}$ phase and increased the number of cells in G2/M phase, although that increase was non-significant (Fig. 5). That pattern was repeated with $40 \mu \mathrm{M}$ salinomycin, although the difference was also non-significant compared to the control.

\section{Cell death analysis}

\section{Flow cytometry (Annexin V/Propidium iodide)}

For all cell lines studied, the flow cytometric analysis of apoptosis induction showed no significant difference between the number of cells at initial apoptosis (AV+/PI-) in treatments with salinomycin exposure compared to the control group. 
Fig. 2 Mean and standard deviation of absorbance values obtained using the MTT cytotoxicity assay in MCF-7 (a) and HB4a (b) cells after 24, 48, or $72 \mathrm{~h}$ of exposure to vehicle control (DMSO $0.25 \%$; PBS $0.5 \%$ ), to $5,10,20,40$, or $80 \mu \mathrm{M}$ salinomycin or to $5 \mu \mathrm{M}$ Doxorubicin. *Significantly different from the control $(p<0.05)$
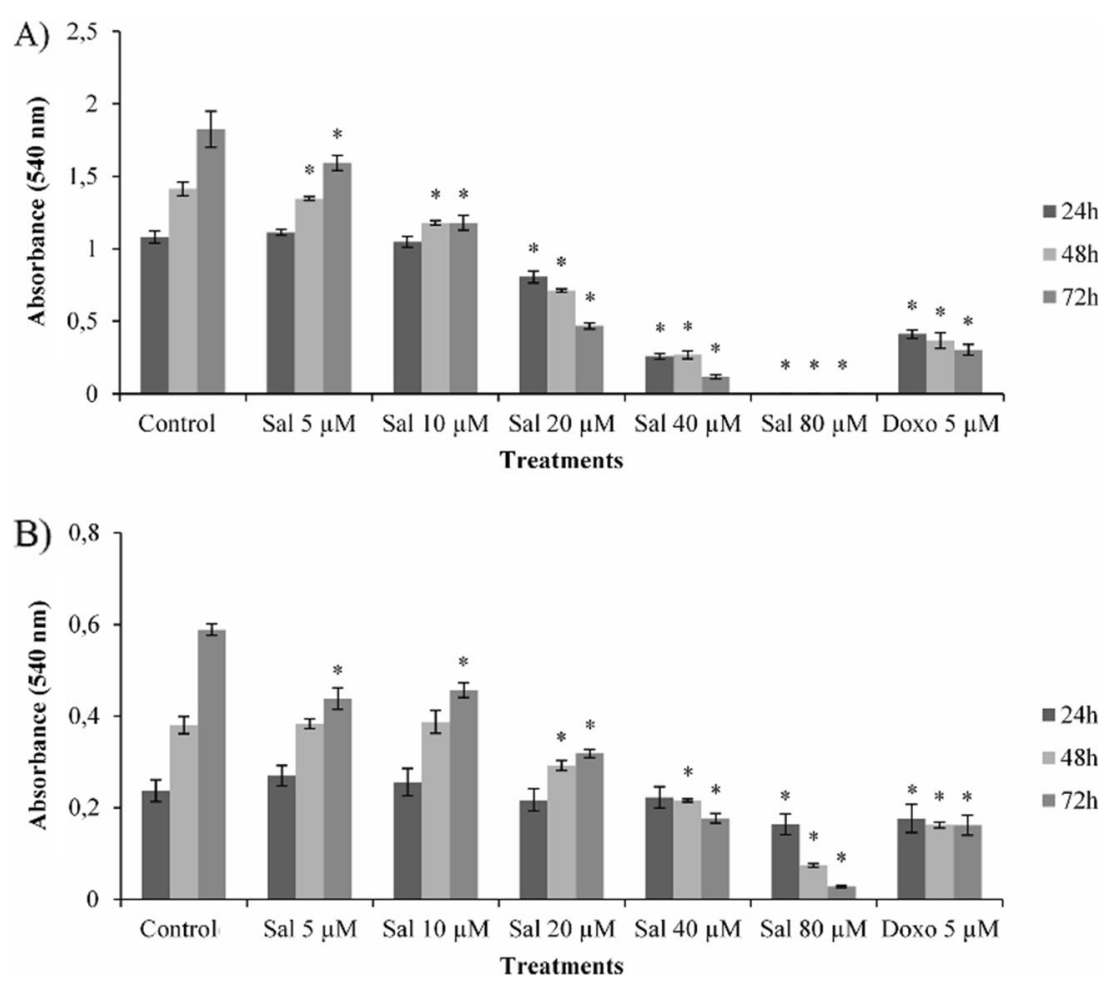

Reduced cell viability and death by late apoptosis/necrosis $(\mathrm{AV}+/ \mathrm{PI}+$ and $\mathrm{AV}-/ \mathrm{PI}+)$ only occurred in the MCF-7 tumor cell line after $24 \mathrm{~h}$ of exposure to $40 \mu \mathrm{M}$ salinomycin (Fig. 6). Conversely, no effect was observed in the non-tumor cell line $\mathrm{HB} 4 \mathrm{a}$, in which cell viability remained very similar to the control group at all salinomycin concentrations tested (Fig. 7).

\section{Hoechst 33342 staining}

Light microscopy images showed the occurrence of an increased number of small, round cells (black arrows), typical of cells entering apoptosis, in MCF-7 tumor cell line exposed to $40 \mu \mathrm{M}$ salinomycin (Fig. 6). Fluorescence imaging of cells labeled with Hoechst 33342 showed that salinomycin induced apoptotic death in MCF-7 tumor cells (white arrows), whereas

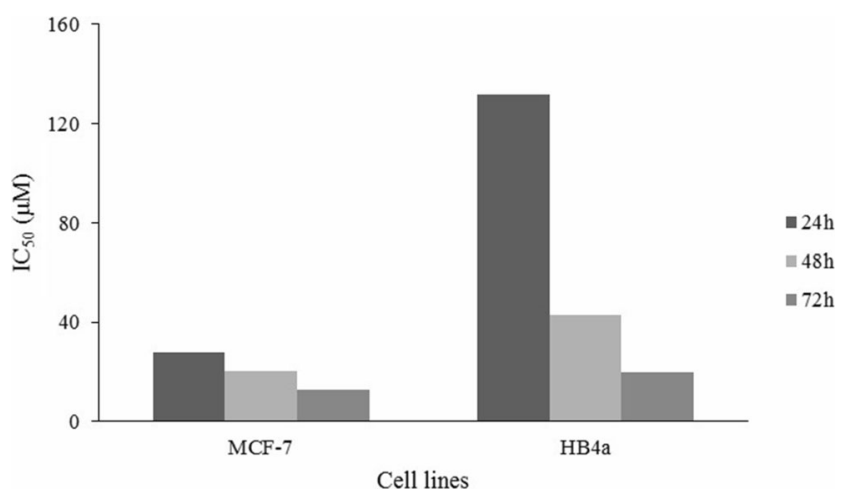

Fig. $3 \mathrm{IC}_{50}$ values $(\mu \mathrm{M})$ of salinomycin in MCF-7 and HB4a cells after 24,48 , or $72 \mathrm{~h}$ of treatment few apoptotic cells were observed in the non-tumor cell line HB4a (Figs. 6 and 7, respectively). Those data confirm the apoptotic cell death detected by flow cytometry in MCF-7 tumor cells.

\section{RT-qPCR}

The expression analysis of genes involved in the cell cycle showed significant increases in the expression levels of GADD45A (3.5 MCF-7; $4.5 \mathrm{HB} 4 \mathrm{a})$ and CDKN1A (4.2 MCF-7; $11.1 \mathrm{HB} 4 \mathrm{a})$ and decreases in the expression levels of TP53 (4.7 MCF-7; $2 \mathrm{HB} 4 \mathrm{a}$ ) and CCNA2 (11.8 MCF-7; $2.5 \mathrm{HB} 4 \mathrm{a})$ in all cell lines studied, as shown in Fig. 8. Downregulation of $C C N B 1$ gene was also observed in MCF-7 cells in 2.6-fold change, as shown in Fig. 8a. Regarding genes involved in apoptotic cell death, the MCF7 tumor cell line showed a marked decrease in the expression of the antiapoptotic gene $B C L-2$ in 14.1-fold change, as shown in Fig. 9a. Besides, MCF-7 cells showed downregulation of $B A K$ (3.9), BCL-XL (6.5), CASP8 (4.1), and BIRC5 (2.1). As shown in Fig. 9b, the non-tumor HB4a cells showed upregulation of $B A K(2.0)$ and $C A S P 9$ downregulation (2.3).

\section{Discussion}

The search for new anticancer drugs is a major scientific challenge. The large increase in cancer cases worldwide demonstrates the importance of research seeking more efficient drugs 
Fig. 4 Mean and standard deviation of the score obtained in 600 comets analyzed using the Comet Assay in MCF-7 (a) and HB4a (b) cells exposed to vehicle control (0.06 \% DMSO; $0.05 \%$ PBS), to 10,20 , and $40 \mu \mathrm{M}$ salinomycin, or to $1 \mu \mathrm{M}$ doxorubicin for $3 \mathrm{~h}$.

* Significantly different from the control $(p<0.05)$

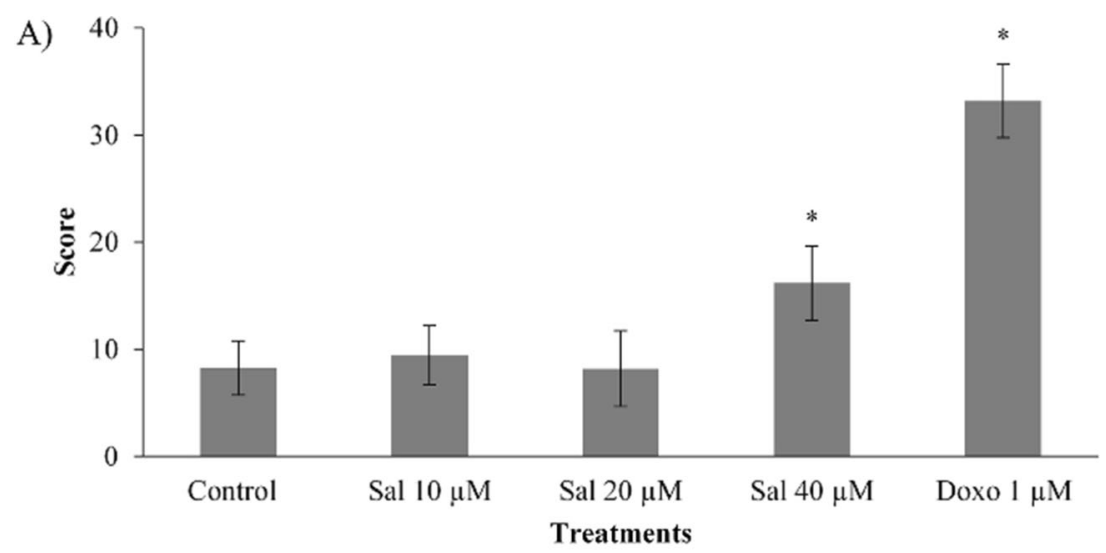

B)

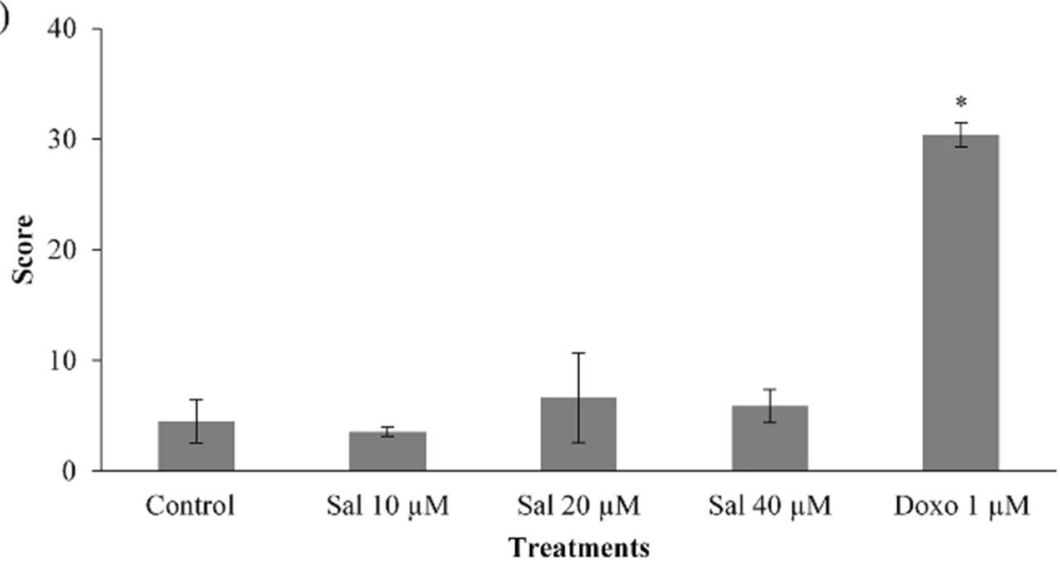

that improve patients' quality of life. Salinomycin is a promising anticancer drug and some mechanisms of action have been examined, including apoptosis induction (Fuchs et al. 2009; Wang et al. 2012; Zhou et al. 2013; Fuchs et al. 2010), DNA damage induction (Kim et al. 2011), Pglycoprotein activity inhibition (Kim et al. 2011), autophagy induction (Li et al. 2013; Jangamreddy et al. 2013), oxidative stress induction ((Ketola et al. 2012; Zhou et al. 2013), and trypanocidal activity (Steverding and Sexton 2013).

We observed that salinomycin decreased the proliferation of MCF-7 tumor cells more efficiently than that of HB4a nontumor cells. These results confirm the selective activity of salinomycin against tumor cells reported in the literature in immortalized non-tumor human mammary epithelial cells (HMLE) (Callaway et al. 2003), in CD4 ${ }^{+}$T cells isolated from peripheral blood of healthy individuals (Fuchs et al. 2009) and in non-malignant prostate epithelial cells (Ketola et al. 2012). In addition to selectively destroying tumor cells, studies have shown that salinomycin can destroy cells that are resistant to apoptotic cell death (Fuchs et al. 2009). Our cytotoxicity assay also corroborated the data obtained in the cell proliferation assay (RTCA), showing that salinomycin is more cytotoxic to tumor cells than non-tumor cell lines.

Other authors (Al Dhaheri et al. 2013) also showed that salinomycin $(2.5$ to $50 \mu \mathrm{M})$ causes a reduction in MCF-7 cell viability after 24 and $48 \mathrm{~h}$ of treatment the maner concentration and time dependent. We study showed more resistance of $\mathrm{HB} 4 \mathrm{a}$ cells to salinomycin, confirmed again because the $\mathrm{IC}_{50}$ values were higher than the tumor cells, especially at 24 and $48 \mathrm{~h}$. The $\mathrm{IC}_{50}$ values at a density of 5000 cells were $40 \mu \mathrm{M}(24 \mathrm{~h})$ and $15 \mu \mathrm{M}$ (48 h). In MCF-7, the authors (Al Dhaheri et al. 2013) finding values different to those obtained in the present study, which were $28 \mu \mathrm{M}(24 \mathrm{~h})$ and $20 \mu \mathrm{M}$ (48 h); here, the difference may be attributed to the variations in the cell density used. The concentrations used in this work were defined by kinetics growth obtained in RTCA assay titration, which is used to assess the optimal number of cells for each cell line.

After identifying the concentrations that lead to decreased cell proliferation, the mechanism of action of salinomycin was assessed regarding the capacity to induce DNA damage. The comet assay showed that only the highest salinomycin concentration tested (40 $\mathrm{MM}$ ) was genotoxic only to MCF-7 cells. Salinomycin was not genotoxic to HB4a cells at all concentrations tested. The induction of damage observed in MCF-7 cells may account for the decreased growth observed in the cell proliferation and cytotoxicity analyses. There are reports that salinomycin induces double-strand DNA breaks in MDAMB-231 breast cancer cells, resulting in apoptotic cell death when cells are exposed to high concentrations of salinomycin (25 and $50 \mu \mathrm{M}$ ) (Al Dhaheri et al. 2013). Conversely, 
A)
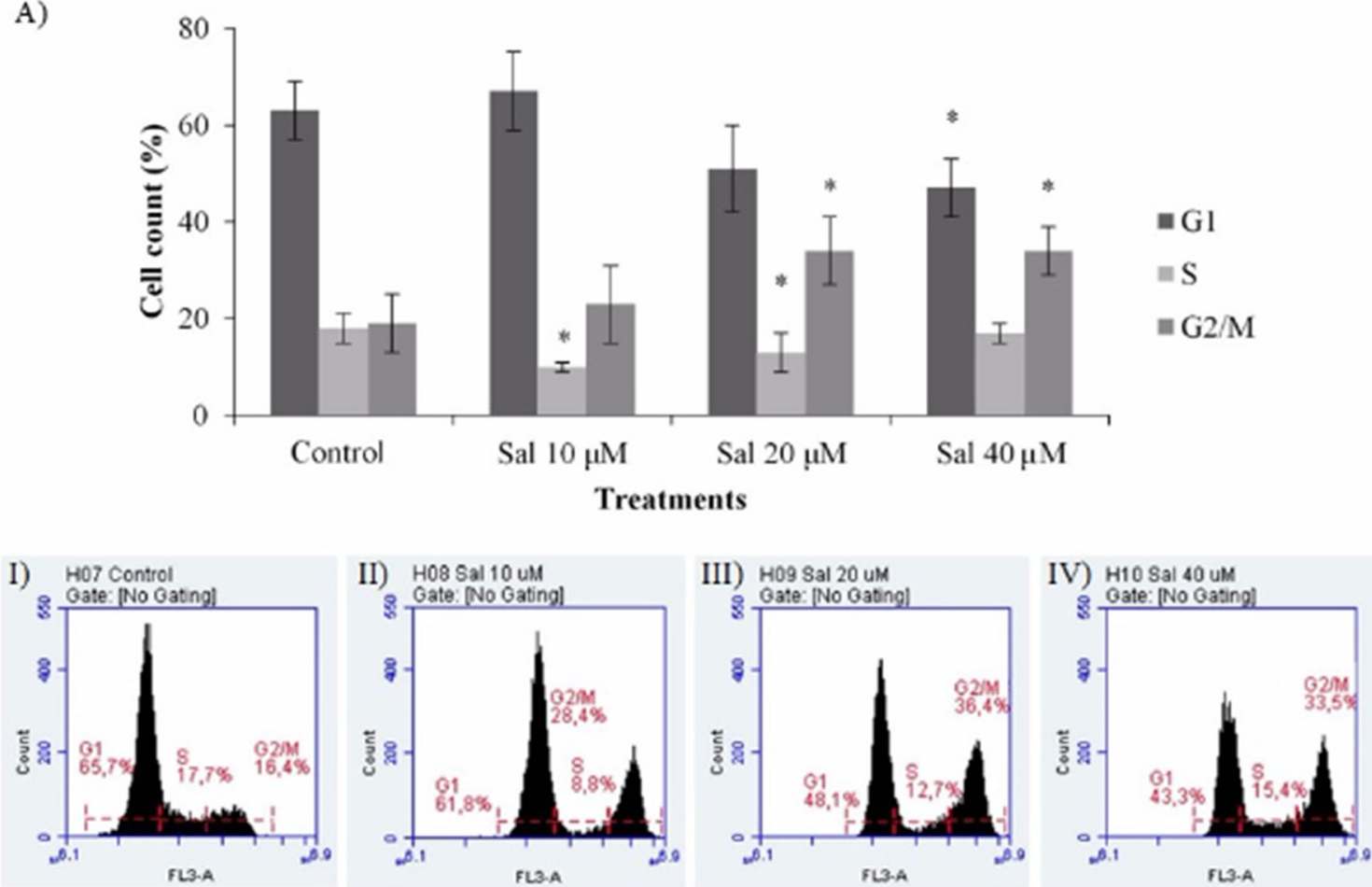

B)
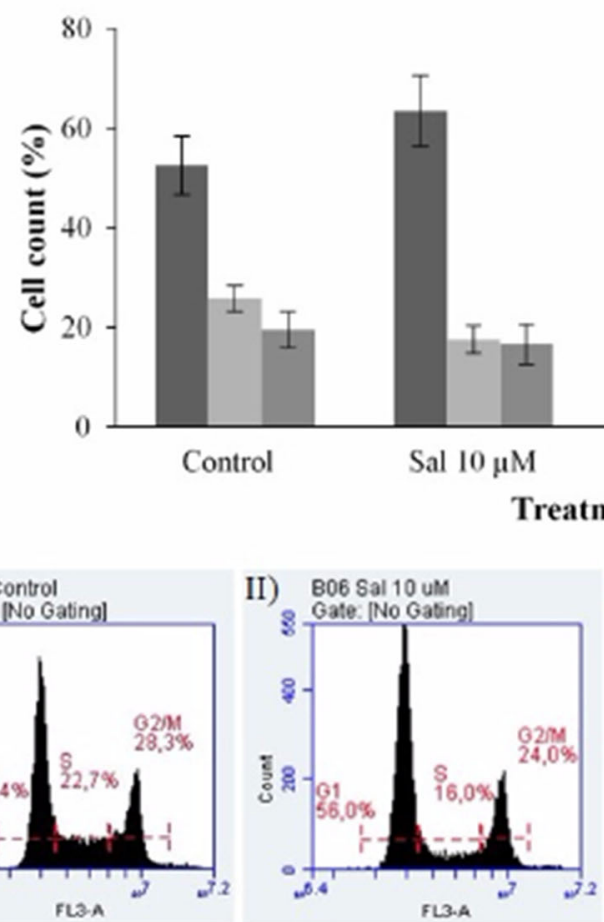

Fig. 5 Cell cycle analysis by flow cytometry in a MCF-7 cells and b HB4a cells. Cell cycle effects of exposure to vehicle control $(0.06 \%$ DMSO; $0.05 \%$ PBS) and to 10,20 , or $40 \mu \mathrm{M}$ salinomycin. Data are expressed as the mean and standard deviation of the percentage of cells at
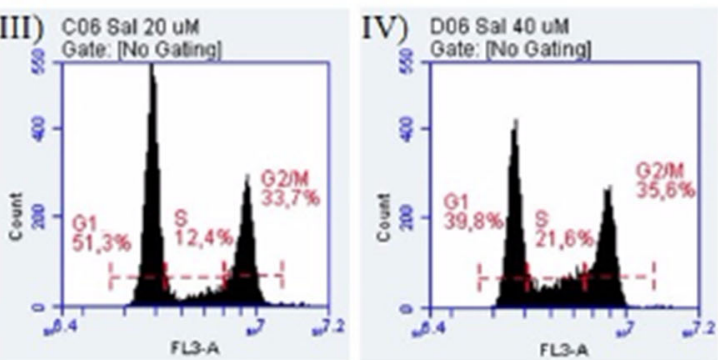

the cell cycle phases $\mathrm{G} 1, \mathrm{~S}$, and $\mathrm{G} 2 / \mathrm{M}$ in three independent experiments. (I) vehicle control, (II) $10 \mu \mathrm{M}$ salinomycin, (III) $20 \mu \mathrm{M}$ salinomycin, and (IV) $40 \mu \mathrm{M}$ salinomycin. *Significantly different from the control $(p<0.05)$

salinomycin triggers cell senescence when applied at low concentrations (up to $10 \mu \mathrm{M}$ ) (Al Dhaheri et al. 2013).

Although no DNA damage was observed in HB4a cells using the comet assay, after $24 \mathrm{~h}$ of exposure to $40 \mu \mathrm{M}$ 

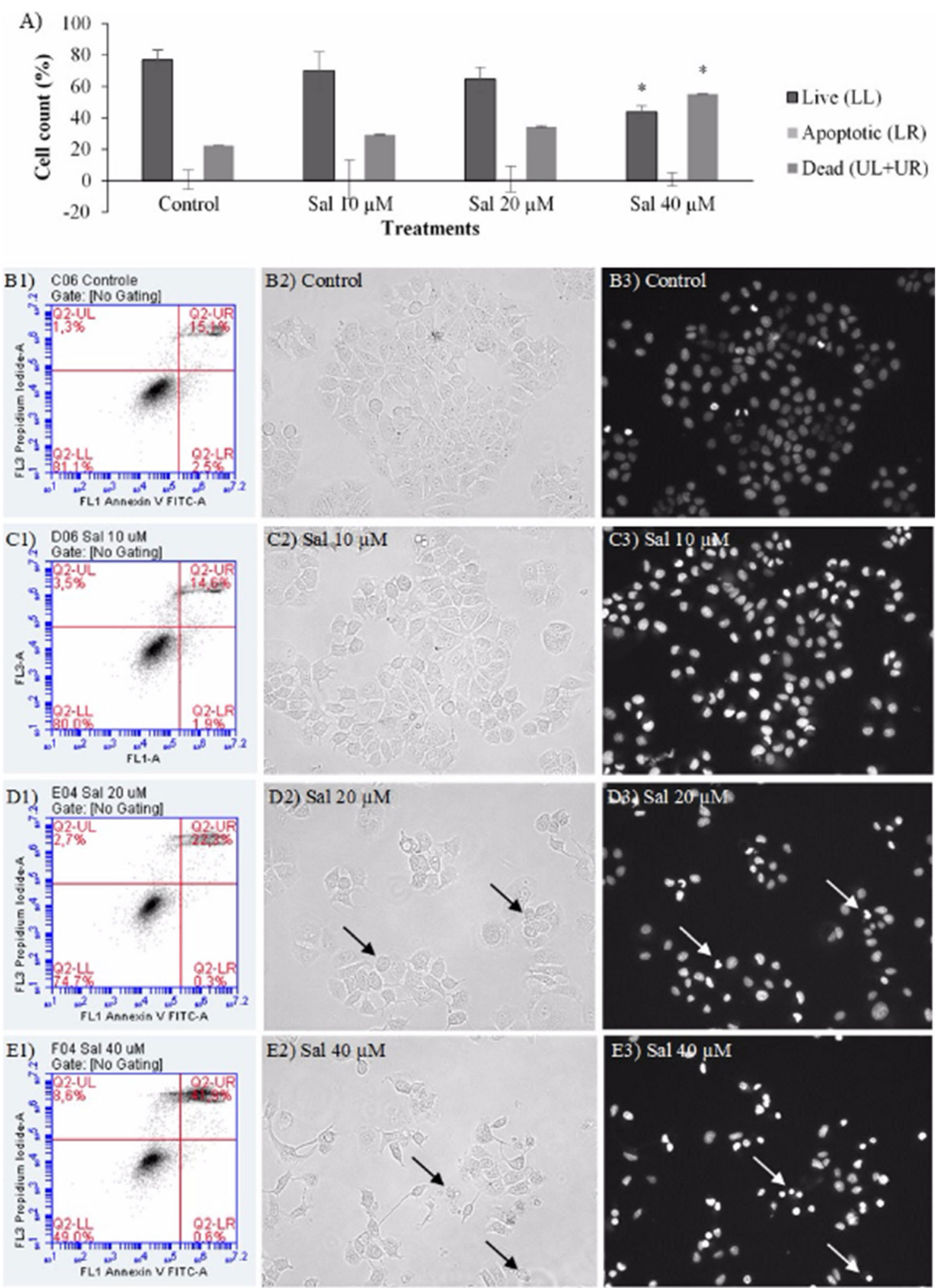

Fig. 6 Flow cytometric analysis (Annexin V/PI) of apoptotic cell death in MCF-7 cells (Annexin V/PI). a Percentages of viable cells in early apoptosis and late apoptosis /necrosis after $24 \mathrm{~h}$ of exposure to vehicle control $(0.06 \%$ DMSO; $0.05 \%$ PBS $)$ and to 10,20 or $40 \mu \mathrm{M}$ salinomycin. ( $B 1$ to $E 1)$ Quantification of viable cells in early apoptosis and late apoptosis/necrosis after $24 \mathrm{~h}$ of exposure to vehicle control or to
10, 20 or $40 \mu \mathrm{M}$ salinomycin. (B2 to E2) Light microscopy images of cells exposed to vehicle control or to 10,20 , or $40 \mu \mathrm{M}$ salinomycin for 24 h. (B3 to E3) Fluorescence microscopy images of cells stained with Hoechst 33342 exposed to vehicle control or to 10,20 , or $40 \mu \mathrm{M}$ salinomycin for $24 \mathrm{~h}$. Arrows indicate apoptotic cells; $460 \times$ magnification. *Significantly different from the control $(p<0.05)$ 
A)
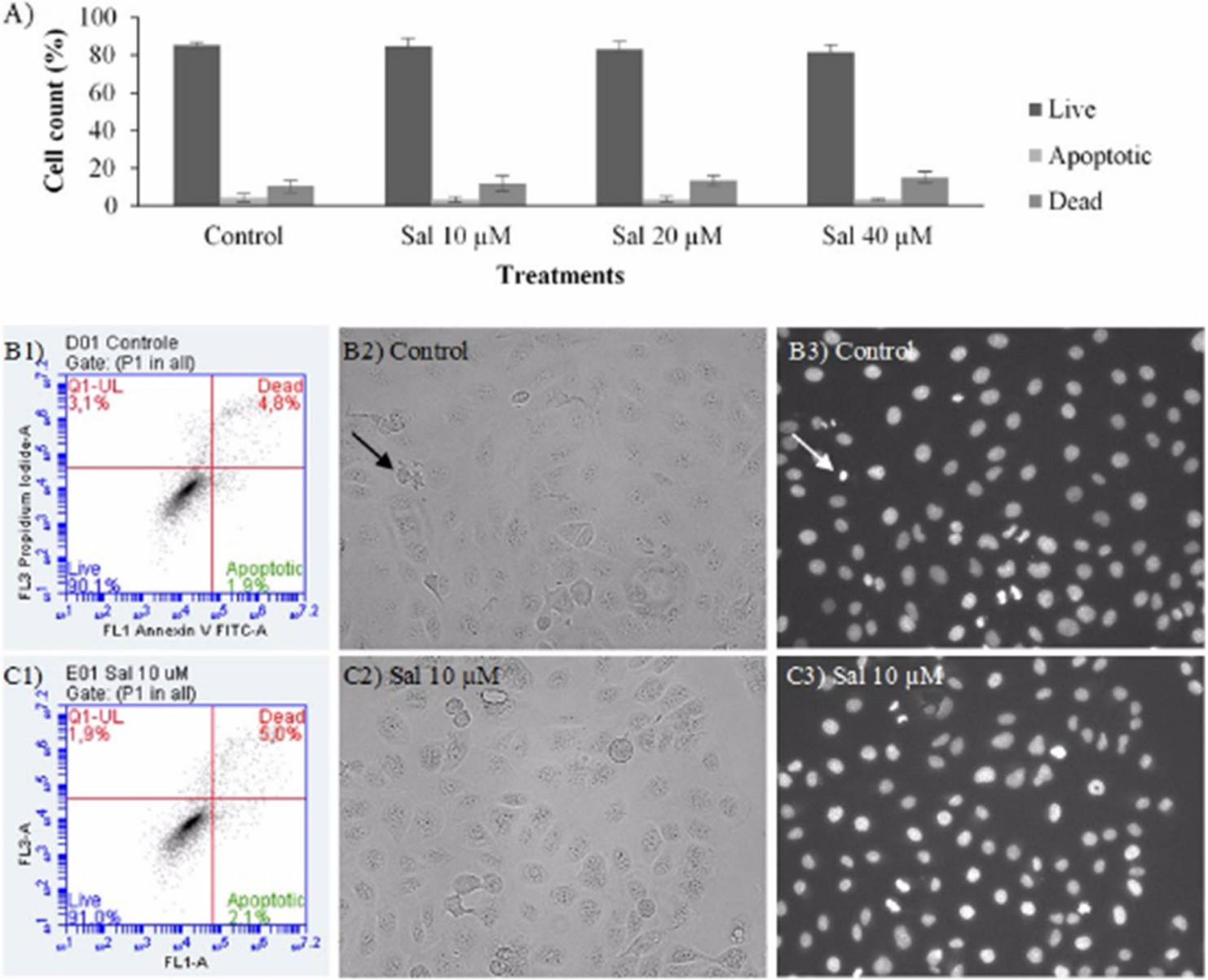

D1) F01 8 al 20 uM
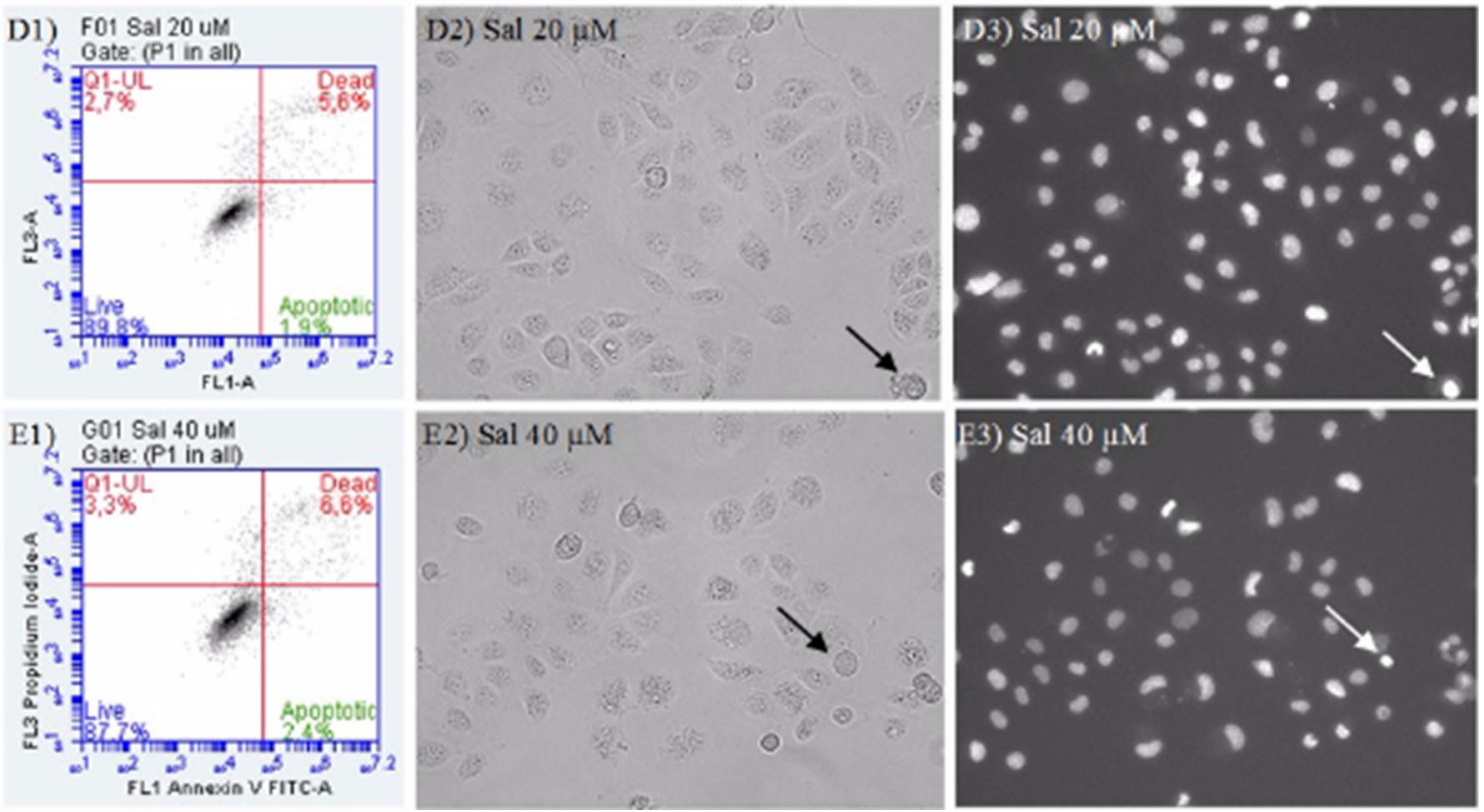

Fig. 7 Flow cytometric analysis (Annexin V/PI) of apoptotic cell death in HB4a cells (Annexin V/PI). a Percentages of viable cells in early apoptosis and late apoptosis /necrosis after $24 \mathrm{~h}$ of exposure to vehicle control (0.06\% DMSO; $0.05 \%$ PBS) and to 10,20 , or $40 \mu \mathrm{M}$ salinomycin. ( $B 1$ to $E 1$ ) Quantification of viable cells in early apoptosis and late apoptosis/necrosis after $24 \mathrm{~h}$ of exposure to vehicle control or to

10, 20, or $40 \mu \mathrm{M}$ salinomycin. (B2 to E2) Light microscopy images of cells exposed to vehicle control or to 10,20 or $40 \mu \mathrm{M}$ salinomycin for 24 h. (B3 to E3) Fluorescence microscopy images of cells stained with Hoechst 33342 exposed to vehicle control or to 10,20 , or $40 \mu \mathrm{M}$ salinomycin for $24 \mathrm{~h}$. Arrows indicate apoptotic cells; 460× magnification. *Significantly different from the control $(p<0.05)$ 
Fig. 8 Relative expression levels of genes related to DNA damage $(G A D D 45 A)$ and the cell cycle (CDKN1A, TP53, CCNA2, $C C N B 1$, and $C T N N B 1$ ) obtained by real time RT-PCR after $24 \mathrm{~h}$ of exposure to $40 \mu \mathrm{M}$ salinomycin in MCF-7 a and HB4a b cells. The data were normalized using the genes GAPDH, ACTB, and $R P L 13 A . *$ Statistically significant difference determined using the software parameters REST-384 (48) and with relative expression higher than 2 or lower than -2
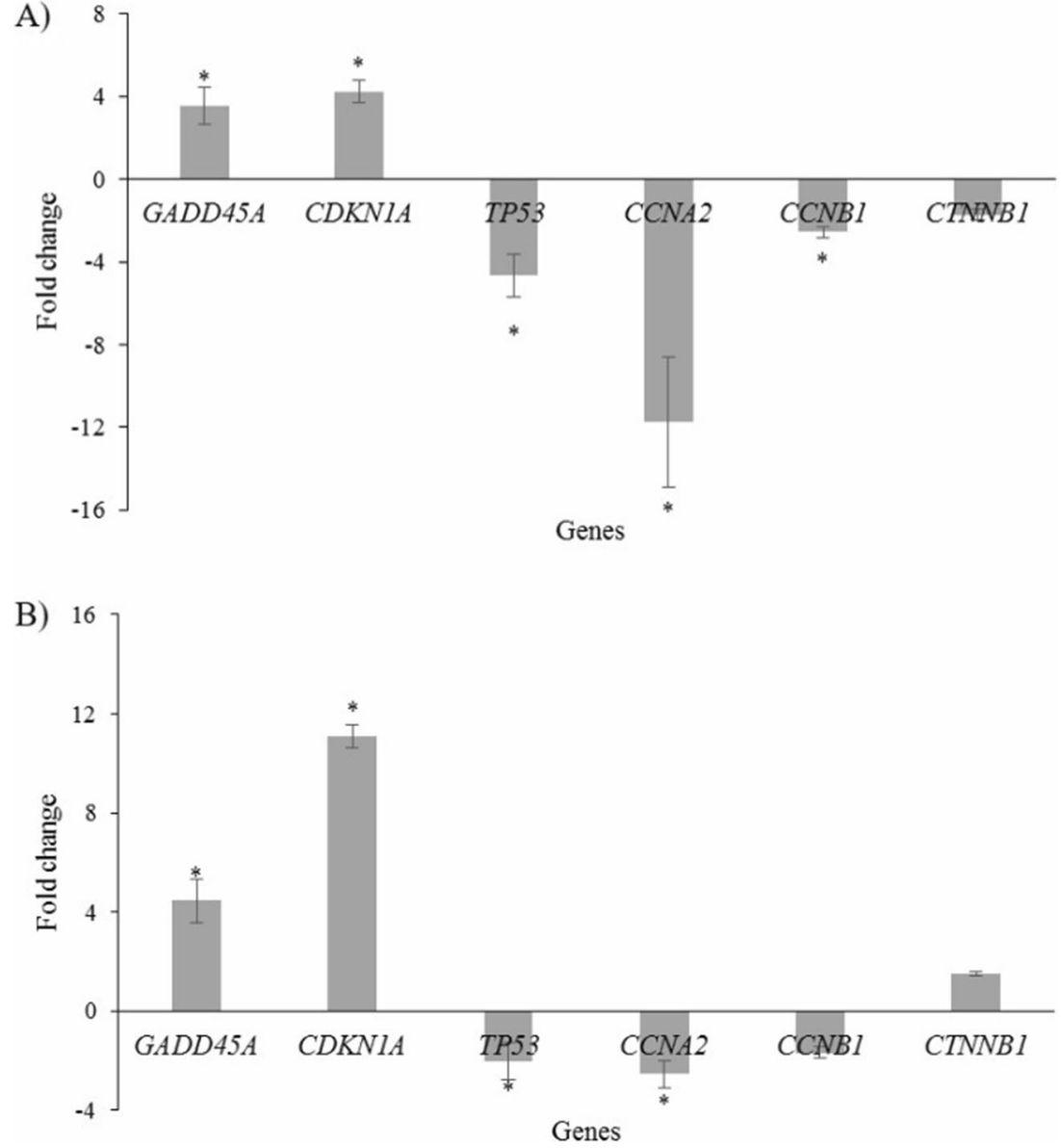

salinomycin, the expression of GADD45A (growth arrest and DNA damage inducible, alpha) showed significant increases in all cell lines tested. The transcript levels of that gene increase upon cellular stress induced by DNA damage, which may result in cell cycle arrest, DNA repair, senescence, or apoptosis (Liebermann and Hoffman 2008).

Upon cell cycle arrest, the DNA damage may be repaired or apoptotic cell death may be activated. To determine whether cell cycle arrest occurs, the MCF-7 and HB4a cell lines were assessed by flow cytometry. Non-significant increase in $\mathrm{G} 2 / \mathrm{M}$ arrest was observed in MCF-7 and HB4a cells. The $G A D D 45 A$ gene regulates the $\mathrm{G} 2 / \mathrm{M}$ checkpoint (Wang et al. 1999), inhibiting the Cdk1/Cyclin B1 complex (Zhan et al. 1999), which is required for progression to mitosis. Decreased expression of $C C N B 1$, which encodes cyclin B1, was also observed in MCF-7 tumor cell lines suggesting G2/ M. Furthermore, these cells showed increased expression of the $C D K N 1 A$, gene encoding $\mathrm{p} 21$, which may also inhibit the cyclin/Cdk complex and inhibit DNA replication, resulting in G2/M cell cycle arrest (Medema et al. 1998). In addition to cyclin B1 in the tumor cell line, decreased expression of CCNA2, which encodes cyclin A2, was observed in all cell lines studied. Despite the $C C N B 1$ downregulation in tumor cells, we observed decreased expression of TP53. Previous reports have indicated that the regulation of checkpoint G2/ M may occur independent of p53 (Zhan et al. 1999) and that salinomycin can increase p21 levels independent of p53 (Al Dhaheri et al. 2013).

Salinomycin-induced reduction in cell proliferation caused by $\mathrm{G} 2 / \mathrm{M}$ cell cycle arrest has also been reported time- and dose-dependent form in MDA-MB-231 human breast tumor cells after exposure to 10 or $25 \mu \mathrm{M}$ salinomycin and decreased cyclin B1 expression, confirming the $\mathrm{G} 2$ cell cycle arrest (A1 Dhaheri et al. 2013).

In addition to cell cycle arrest, reduced cell proliferation may result from induced apoptotic cell death. In the present study, $40 \mu \mathrm{M}$ salinomycin reduced the number of viable cells and increased the population of cells in final apoptosis/ necrosis only in MCF-7 tumor cells after $24 \mathrm{~h}$ of treatment. The images taken after staining the cells with Hoechst 33342 corroborate the flow cytometric data, wherein a higher number of cells in final apoptosis were observed. Cell death induction may have resulted from the cell cycle arrest that was also observed by flow cytometry. No change was observed in nontumor cells HB4a, again showing its higher resistance to salinomycin compared to the MCF-7 tumor cell line. Other 
Fig. 9 Relative expression of the apoptosis-related genes (CASP3, CASP7, CASP8, CASP9, BAX, $B A K, B C L-2, B C L-X L$, and $B I R C 5$ ) obtained by real time RTPCR after $24 \mathrm{~h}$ of exposure to $40 \mu \mathrm{M}$ salinomycin in MCF-7 (a) and HB4a (b) cells. The data were normalized using the genes $G A P D H, A C T B$, and RPL13A. *Statistically significant difference determined using the software parameters REST-384 (48) and with relative expression higher than 2 or lower than -2
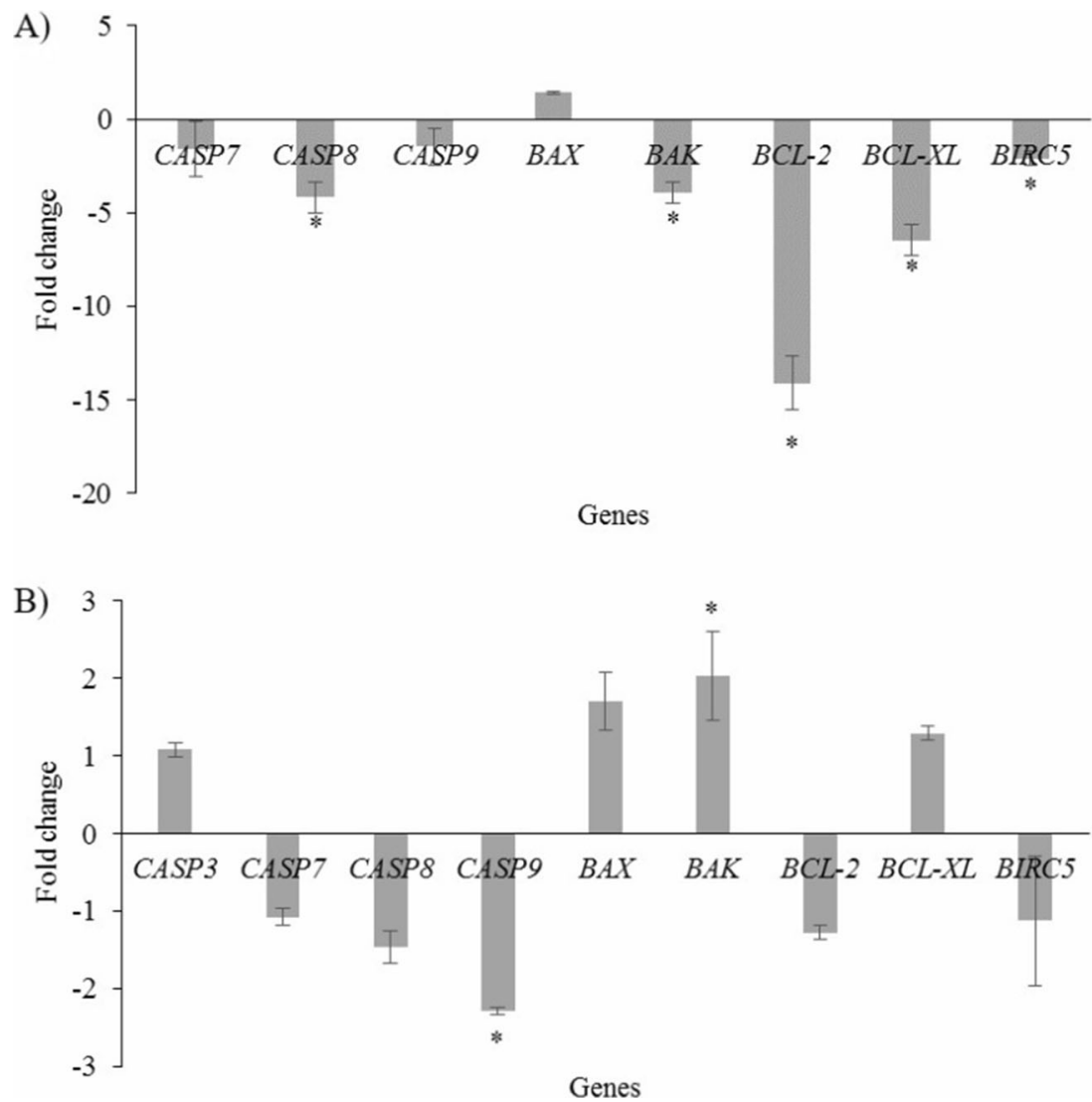

studies also reported salinomycin-induced apoptosis in tumor cell lines (Fuchs et al. 2009; Kim et al. 2011; Kim et al. 2012; Wang et al. 2012; Al Dhaheri et al. 2013; Zhou et al. 2013; Lee et al. 2014; Wu et al. 2014).

To investigate the mechanism underlying salinomycin activity, the expression of apoptosis-related genes was assessed. Salinomycin-induced cell death in tumor cell line may be associated with the marked decrease in the expression of the antiapoptotic gene $B C L-2$, whose expression was 14.1 times lower in MCF-7 cells compared to the control. In addition to the decrease in BCL-2 expression, MCF-7 cells showed reduced expression of the antiapoptotic genes $B I R C 5$, encoding the protein survivin, and $B C L-X L$. The induction of apoptosis by salinomycin independent of p53 and without caspase activation has also been reported in other studies (Fuchs et al. 2009; Ketola et al. 2012). Our data corroborate the results previously reported, when decreased levels of the protein survivin were reported following exposure to 25 or $50 \mu \mathrm{M}$ salinomycin for 24 or $48 \mathrm{~h}$, sensitizing human breast cancer cells MD-MB-231 to death (Al Dhaheri et al. 2013). Downregulation of $B C L-X L$ by salinomycin was also observed in colorectal cancer cells (Zhou et al. 2013) and in primary culture cells of human uterine leiomyoma (Lee et al. 2014). Our results are also consistent with those of other studies reporting the induction of apoptosis and decreased expression of $B C L-2$ following exposure to salinomycin (Kusunoki et al. 2013; Lee et al. 2014). Conversely, increased expression of $B A K$ occurred in the non-tumor cell line HB4a, albeit with reduced expression of $C A S P 9$, which may have prevented the induction of the apoptotic cascade in those cells. Previous studies have also reported the decreased expression of CASP9 as a strategy for preventing apoptotic cell death $(\mathrm{Xu}$ et al. 2010; Maheshwari et al. 2011). The present work is the first study of the effect of salinomycin on (HB4a) non-tumor breast cells.

\section{Conclusions}

The present study showed the selective activity of salinomycin against tumor cells. Salinomycin increases the levels of GADD45A and CDKN1A, leading to decreased expression of cyclin A2 and B1 and resulting in G2/M cell cycle arrest in the MCF-7 tumor cell line. As a result of the cell cycle arrest, cell death is induced in tumor cells through marked reduction of the expression levels of the antiapoptotic gene $B C L-2$ and through inhibition of the antiapoptotic genes $B C L-X L$ and BIRC5. These data suggest the potential of salinomycin as an anticancer drug because tumor cell (MCF7) is more sensitive when compared to non-tumor cells (HB4a) tested. 
Acknowledgments This research was support by CNPq, CAPES, and Fundação Araucária, Brazil.

\section{Compliance with ethical standards}

Conflicts of interest The authors declare no conflicts of interest.

\section{References}

Al Dhaheri Y, Attoub S, Arafat K, Abuqamar S, Eid A, Al Faresi N, et al. (2013) Salinomycin induces apoptosis and senescence in breast cancer: upregulation of $\mathrm{p} 21$, downregulation of survivin and histone $\mathrm{h} 3$ and h4 hyperacetylation. Biochim Biophys Acta 1830:3121-3135

Arafat K, Iratni R, Takahashi T, Parekh K, Al Dhaheri Y, Adrian TE, et al. (2013) Inhibitory effects of salinomycin on cell survival, colony growth, migration, and invasion of human non-small cell lung cancer a549 and lnm35: involvement of nag-1. PLoS one 8:e66931

Boehmerle W, Endres M (2011) Salinomycin induces calpain and cytochrome c-mediated neuronal cell death. Cell Death Dis 2:e168

Callaway TR, Edrington TS, Rychlik JL, Genovese KJ, Poole TL, Jung YS, et al. (2003) Ionophores: their use as ruminant growth promotants and impact on food safety. Curr Issues Intest Microbiol $4: 43-51$

Chari RV (2008) Targeted cancer therapy: conferring specificity to cytotoxic drugs. Acc Chem Res 41:98-107

Chazotte B (2011) Labeling nuclear DNA with hoechst 33342. Cold Spring Harbor protocols 2011:pdb.prot5557.

Eyler CE, Rich JN (2008) Survival of the fittest: cancer stem cells in therapeutic resistance and angiogenesis. J Clin Oncol 26:2839-2845

Fuchs D, Daniel V, Sadeghi M, Opelz G, Naujokat C (2010) Salinomycin overcomes Abc transporter-mediated multidrug and apoptosis resistance in human leukemia stem cell-like kg-1a cells. Biochem Biophys Res Commun 394:1098-1104

Fuchs D, Heinold A, Opelz G, Daniel V, Naujokat C (2009) Salinomycin induces apoptosis and overcomes apoptosis resistance in human cancer cells. Biochem Biophys Res Commun 390:743-749

Griffiths GL, Hillier P, Sutherland RJ (1989) Salinomycin poisoning in point-of-lay turkeys. Aust Vet J 66:326-329

Gupta PB, Onder TT, Jiang G, Tao K, Kuperwasser C, Weinberg RA, et al. (2009) Identification of selective inhibitors of cancer stem cells by high-throughput screening. Cell 138:645-659

He L, Wang F, Dai WQ, Wu D, Lin CL, Wu SM, et al. (2013) Mechanism of action of salinomycin on growth and migration in pancreatic cancer cell lines. Pancreatol 13:72-78

Huang YH, Shang BY, Zhen YS (2005) Antitumor efficacy of lidamycin on hepatoma and active moiety of its molecule. World J Gastroentero 11:3980-3984

Ivanova J, Pantcheva IN, Mitewa M, Simova S, Tanabe M, Osakada K (2011) $\mathrm{Cd}$ (ii) and pb(ii) complexes of the polyether ionophorous antibiotic salinomycin. Chem Central J 5:52

Jangamreddy JR, Ghavami S, Grabarek J, Kratz G, Wiechec E, Fredriksson BA, et al. (2013) Salinomycin induces activation of autophagy, mitophagy and affects mitochondrial polarity: differences between primary and cancer cells. Biochim Biophy Acta 1833:2057-2069

Janicke RU (2009) Mcf-7 breast carcinoma cells do not express caspase3. Breast Cancer Res Tr 117:219-221

Kavanagh NT, Sparrow D (1990) Salinomycin toxicity in pigs. Vet Rec 127:507
Ketola K, Hilvo M, Hyotylainen T, Vuoristo A, Ruskeepaa AL, Oresic M, et al. (2012) Salinomycin inhibits prostate cancer growth and migration via induction of oxidative stress. Br J Cancer 106:99-106

Kim JH, Choi AR, Kim YK, Kim HS, Yoon S (2013) Low amount of salinomycin greatly increases akt activation, but reduces activated p70s6k levels. Int J Mol Sci 14:17304-17318

Kim JH, Kim TY, Kim HS, Hong S, Yoon S (2012) Lower salinomycin concentration increases apoptotic detachment in high-density cancer cells. Int J Mol Sci 13:13169-13182

Kim KY, Yu SN, Lee SY, Chun SS, Choi YL, Park YM, et al. (2011) Salinomycin-induced apoptosis of human prostate cancer cells due to accumulated reactive oxygen species and mitochondrial membrane depolarization. Biochem Biophys Res Commun 413:80-86

Koo KH, Kim H, Bae YK, Kim K, Park BK, Lee CH, et al. (2013) Salinomycin induces cell death via inactivation of stat3 and downregulation of skp2. Cell Death Dis 4:e693

Kusunoki S, Kato K, Tabu K, Inagaki T, Okabe H, Kaneda H, et al. (2013) The inhibitory effect of salinomycin on the proliferation, migration and invasion of human endometrial cancer stem-like cells Gynecol Oncol 129:598-605

Lee HG, Lee JM, Shin SJ, Kwon SH, Lee GS, Song CH, et al. (2014) Salinomycin inhibited cell proliferation and induced apoptosis in human uterine leiomyoma cells. Obstet Gynecol Sci 57:501-506

Li T, Su L, Zhong N, Hao X, Zhong D, Singhal S, et al. (2013) Salinomycin induces cell death with autophagy through activation of endoplasmic reticulum stress in human cancer cells. Autophagy 9:1057-1068

Li Y, Fang J, Wu S, Ma K, Li H, Yan X, et al. (2010) Identification and quantification of salinomycin in intoxicated human plasma by liquid chromatography-electrospray tandem mass spectrometry. Anal Bioanal Chem 398:955-961

Liebermann DA, Hoffman B (2008) Gadd45 in stress signaling. J Mol Signal 3:15

Maheshwari A, Misro MM, Aggarwal A, Sharma RK, Nandan D (2011) $\mathrm{N}$-acetyl-1-cysteine counteracts oxidative stress and prevents $\mathrm{h} 2 \mathrm{o} 2$ induced germ cell apoptosis through down-regulation of caspase-9 and jnk/c-jun. Mol Reprod Dev 78:69-79

Martinez-Serra J, Gutierrez A, Munoz-Capo S, Navarro-Palou M, Ros T, Amat JC, et al. (2014) Xcelligence system for real-time label-free monitoring of growth and viability of cell lines from hematological malignancies. OncoTargets Ther 7:985-994

Medema RH, Klompmaker R, Smits VA, Rijksen G (1998) P21waf1 can block cells at two points in the cell cycle, but does not interfere with processive DNA-replication or stress-activated kinases. Oncogene 16:431-441

Miyazaki Y, Shibuya M, Sugawara H, Kawaguchi O, Hirsoe C (1974) Salinomycin, a new polyether antibiotic. J Antibiot 27:814-821

Mosmann T (1983) Rapid colorimetric assay for cellular growth and survival: application to proliferation and cytotoxicity assays. J Immun Methods 65:55-63

Omidi A, Aslani MR, Movassaghi AR, Mohri M, Dadfar M (2010) Accidental salinomycin intoxication in calves. Can Vet J 51:11431145

Pfaffl MW (2001) A new mathematical model for relative quantification in real-time rt-pcr. Nucleic Acids Res 29:e45

Pfaffl MW, Horgan GW, Dempfle L (2002) Relative expression software tool (rest) for group-wise comparison and statistical analysis of relative expression results in real-time pcr. Nucleic Acids Res 30:e36

Rollinson J, Taylor FG, Chesney J (1987) Salinomycin poisoning in horses. Vet Rec 121:126-128

Roshan Moniri M, Young A, Reinheimer K, Rayat J, Dai LJ, Warnock GL (2015) Dynamic assessment of cell viability, proliferation and migration using real time cell analyzer system (rtca). Cytotechnology 67:379-386

Savio AL, da Silva GN, de Camargo EA, Salvadori DM (2014) Cell cycle kinetics, apoptosis rates, DNA damage and tp53 gene expression in 
bladder cancer cells treated with allyl isothiocyanate (mustard essential oil). Mutat Res-Fund Mol M 762:40-46

Steverding D, Sexton DW (2013) Trypanocidal activity of salinomycin is due to sodium influx followed by cell swelling. Parasite Vec 6:78

Story P, Doube A (2004) A case of human poisoning by salinomycin, an agricultural antibiotic. New Zeal Med J 117:U799

Tang QL, Zhao ZQ, Li JC, Liang Y, Yin JQ, Zou CY, et al. (2011) Salinomycin inhibits osteosarcoma by targeting its tumor stem cells. Cancer Lett 311:113-121

Tice RR, Agurell E, Anderson D, Burlinson B, Hartmann A, Kobayashi H, et al. (2000) Single cell gel/comet assay: guidelines for in vitro and in vivo genetic toxicology testing. Environ Mol Mutagen 35: 206-221

van der Linde-Sipman JS, van den Ingh TS, JJ v n, Verhagen H, JG K, AC B, et al. (1999) Salinomycin-induced polyneuropathy in cats: morphologic and epidemiologic data. Vet Pathol 36:152-156

Wang F, He L, Dai WQ, Xu YP, Wu D, Lin CL, et al. (2012) Salinomycin inhibits proliferation and induces apoptosis of human hepatocellular carcinoma cells in vitro and in vivo. PLoS one 7:e50638
Wang XW, Zhan Q, Coursen JD, Khan MA, Kontny HU, Yu L, et al. (1999) Gadd45 induction of a g2/m cell cycle checkpoint. P Natl Acad Sci USA 96:3706-3711

Wu D, Zhang Y, Huang J, Fan Z, Shi F, Wang S (2014) Salinomycin inhibits proliferation and induces apoptosis of human nasopharyngeal carcinoma cell in vitro and suppresses tumor growth in vivo. Biochem Biophys Res Commun 443:712-717

Xu ZR, Hu L, Cheng LF, Qian Y, Yang YM (2010) Dihydrotestosterone protects human vascular endothelial cells from $\mathrm{h}(2) \mathrm{o}(2)$-induced apoptosis through inhibition of caspase-3, caspase-9 and p 38 mapk. Eur J Pharmacol 643:254-259

Zhan Q, Antinore MJ, Wang XW, Carrier F, Smith ML, Harris CC, et al. (1999) Association with cdc2 and inhibition of cdc2/cyclin b1 kinase activity by the p 53-regulated protein gadd45. Oncogene 18: 2892-2900

Zhi QM, Chen XH, Ji J, Zhang JN, Li JF, Cai Q, et al. (2011) Salinomycin can effectively kill aldh(high) stem-like cells on gastric cancer. Biomed Pharmacother 65:509-515

Zhou J, Li P, Xue X, He S, Kuang Y, Zhao H, et al. (2013) Salinomycin induces apoptosis in cisplatin-resistant colorectal cancer cells by accumulation of reactive oxygen species. Toxicol Lett 222:139-145 